\title{
S 523
}

. B94 
(4)

- nllor Ba.

$\lim _{5} 5^{2}$

$\circ \%$

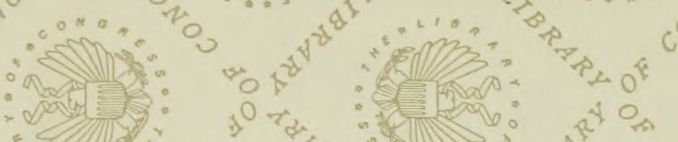

$0 \pi_{2}$
- ellos:

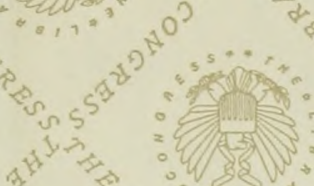
(
$0^{0^{25}}$

:

X

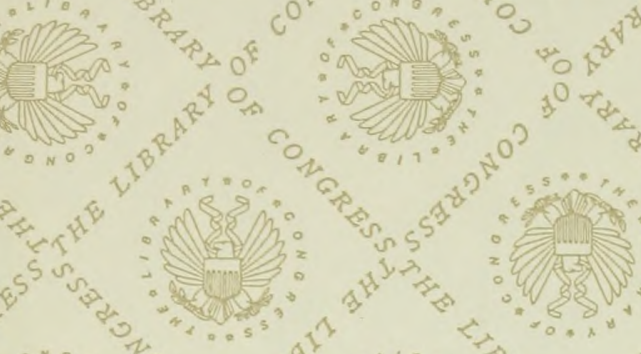

Now $c^{0} \cdot 0^{200}=$

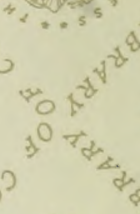
2. 


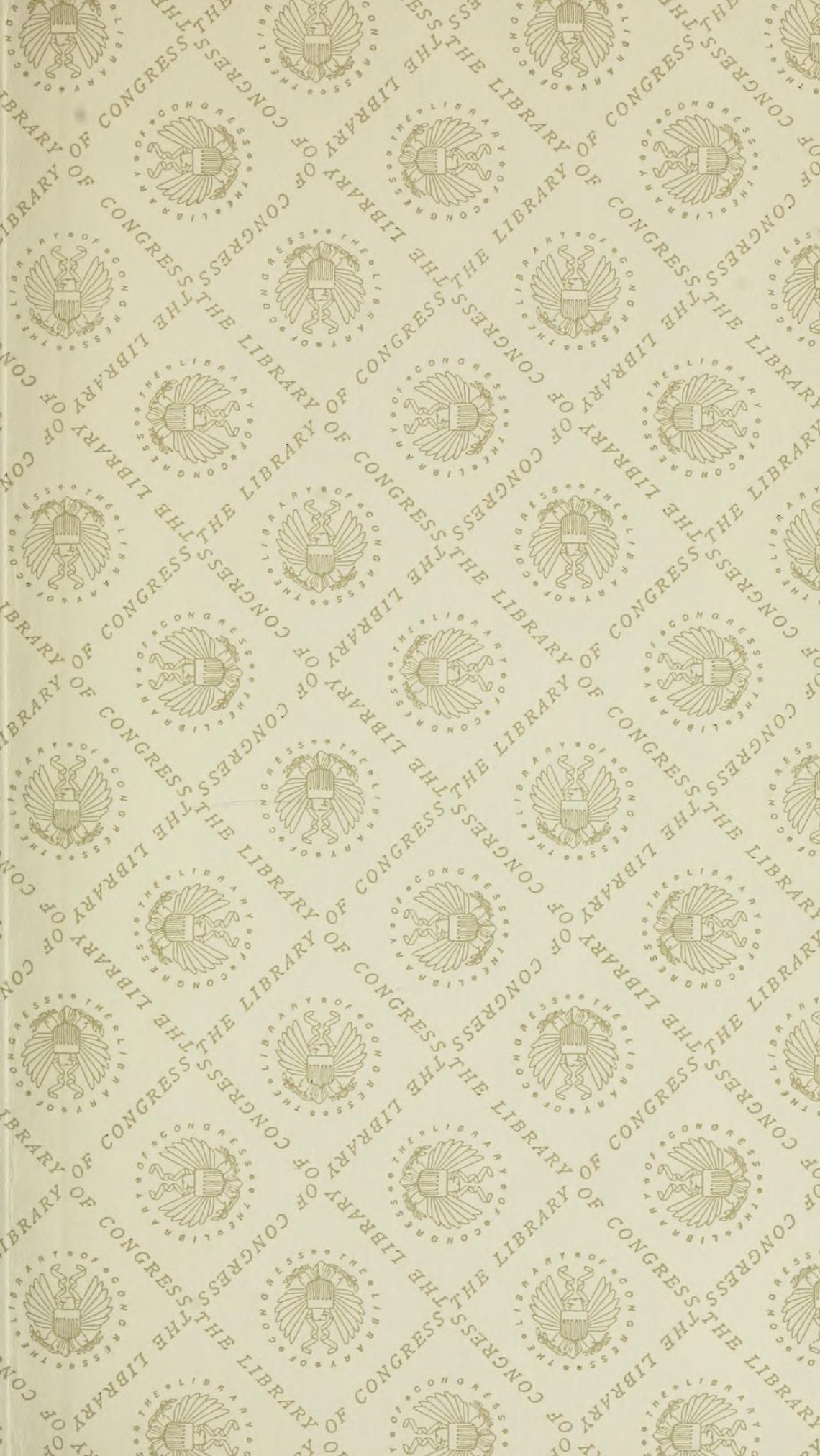




\section{ADDRESS}

TO THE

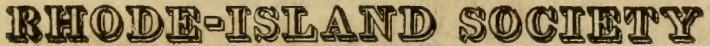

FOR THE ENCOURAGEMENT OF

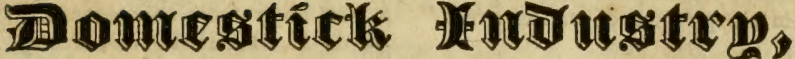

DELIVERED AT PAWTUXET, OCTOBER 17, 1821.

PROVIDENCE :

MILLER AND hUTCHENS, PRINTERS.

August....1822. 


\section{ADDRIRSE.}

THE subjects of domestick industry are the arts of usefulness, The productions of these are, all things needful, in food, raiment, habitation, or equipage. Whatever stimulates domestick industry augments the quantity of the necessaries, conveniences and ornaments of life. Your Society has for its object the encouragement of all these great and important arts. Of some of these, you cannot expect from me, on the present occasion, a description; or a history of them; nor a dissertation concerning their principles or their utility. Those, who consume their productions, know their usefulness ; those, who practice them, are masters of their trades; and those, who employ their capital in them, know, better than I do, what is the process, and what is the result, of such employment. Of these arts, men seem to have been convinced, that it is necessary to have some knowledge, before they enter upon the practice of them; and they have, accordingly, in all countries, devoted a number of years to apprenticeships in them; and have received regular instruction, with as much formality, as young gentlemen are taught the great mysteries of theology, law, or medicine.

There is one art, of which men, either think themselves born masters, or that they can acquire a knowledge of it, without instruction. They seem to rely on taking it the natural way; as the devout Mahomedans do a certain disease; and regard the tedious process of innoculation, both as useless, and 
sinful. This is no new thing. It existed in the days of Columella that great Roman scholar and agriculturalist. In his incomparable book on husbandry he thus complains of it- " I cannot enough wonder why they who desire to learn eloquence are so nice in the choice of an orator whose eloquence they may imitate; and they who search after the knowledge of surveying or mensuration and of numbers, look out for a master of the art they delight in; and they who are desirous of some skill in dancing, and musick, are exceeding scrupulous in their choice of one to modulate their voice and teach them to sing agreeably; and no less of a dancing master to regulate the gestures and motions of their body; also they who have a mind to build send for architects, masons and carpenters; and they who resolve to send ships to sea send for skilful pilots; they who make preparations for war call for men who understand the art of war and are acquainted with military affairs ; and not to mention every particular, in that study which every one resolves to prosecute, he makes use of the wisest and ablest director he can find; finally every one sends for a person from the society and assembly of the wise to form his mind and instruct him in the precept of virtue; but husbandry alone, which without all doubt, is next to, and as it were near akin, to wisdom, is in want of both masters and scholars. For hitherto I have not only heard that there are, but I myself have seen schools of professors of rhetorick, and as I have already said of geometry and of musick or which is more to be wonderedat, academies for the most contemptible vices, for delicately dressing and seasoning victuals, for contriving and making up dainty and costly dishes, for promoting gluttony and luxury; and I have also seen head dressers and hair trimmers; but of agriculture I have never known any that professed themselves either teachers or scholars." 
Rhode-Island is favourably situated for agriculture. Its lands are various, and, most of them, fertile. Clays, sands, loams, hills, vallies and plains, marshes, waters and woods, are sufficiently abundant. It is washed by the sea, indented with bays and interlaced by rivers producing exhaustless quantities of fertilizing materials. The population of this State are industrious, intelligent, brave and independent. When they show themselves to their sister States, as they really are, they do not fail of ready admittance to the very first rank of respectability. Your merchants are enterprising; and deeply read in all the great mysteries of commerce. Your manufacturers, persevering and highly skilful in the application of capital, and the production of fabricks. Your mechanicks, masters of the theory and practice of their trades. Your professional men respectable for talents, learning and character. Your farmers, the independent proprietors of the lands they cultivate, able to command capital sufficient for the management of them, and endowed with all that skill in the great trade of agriculture, which they have hitherto thought proper to acquire or put in practice. Here too, is such an union of all honest men, for the protection of life, liberty, and property, that, notwithstanding they are thought by some people in other States to be insecure in this, yet I dare affirm that there is no spot of earth in all the wide regions of the world, where these great rights are more freely, fully and securely enjoyed than they are in the State of Rhode-Island, by each and every person. With aH these advantages, agriculture seems to have made but little progress for many years in this State. Our merchants have rendered it the fifth commercial State in the Union, and our manufacturers placed it among the first; although our scanty territory would hardly make a county in some of the larger States. What have our agricultural men 
done? Alas! they, with their surplus capital, have built retail shops, or set up banks, or bought spindles; so that they might teach their sons to be traders, or money brokers, or weavers. RhodeIsland was once famed for some agricultural productions. Narraganset horses were, next to Arabian, perhaps, the first in the world; but the race is extinct. The same country was celebrated for cheese; but the secret of making it is lost, or has been stolen by those, who, in place of it, now make not the very best butter. Bristol is famed for the production of onions; and the island of Rhode-Island, for that of barley; and both deservedly so; but they both owe all their success to the marine manure, by the ever labouring ocean, thrown upon their shores; and these farmers could no more succeed in raising these crops, in Smithfield, or Cumberland, than a porpus could live and fatten on Nutaconkanut Hill.

But Rhode-Island farmers are not, in this respect, sinners above all the Americans. The people of this country seem to have thought that farming consisted, in clearing the land of trees and bushes, and then driving it with crops of grain, until it was dead. They have treated the earth like a step dame ; and not like a mother whose uberious bosom feeds and fosters her millions of children. It is true a spirit of improvement seems for the last twenty years to have gone abroad in our country. Some fine agricultural productions are brought forward and exhibited to the publick. So far it is well. I rejoice at it. But it cannot be forgotten that this is holy-day husbandry. Look minutely through the country, if you would know the state of agriculture. Travel like Arthur Young - see the farm yards and fields-observe the instruments of tillage, the course of crops, the system of manuring. I fear we shall find, we are, taken in a mass, about such farmers, as our forefathers were, when they 
migrated to this country. They, we know, were such farmers, as their fathers were when they left England. But all the capital improvements, in agriculture, have been made, in that country, since the settlement of this.

If it were in the course of nature for the venerable pilgrims of Plymouth again to land on the shores of that island, they would not know the fields of their native country. Not many years before they migrated the London market was supplied with vegetables from Flanders, and the English climate and soil were deemed incapable of producing them. At this time 14,000 acres are appropriated to gardening in the immediate neighbourhood of that metropolis, and the vegetables and fruit raised on those lands, are sold in that city for a sum little short of four millions of dollars per annum. The rent of land in the county of Norfolk, the least fertile, but the best farmed district of England, has increased within the memory of man, eight fold. The rent roll of Mr. Coke, the great Norfolk farmer, has, in that time, risen from five to 40,000l. per annum. This has been done, not by grinding his tenants, but by enriching them; by granting them leases of his lands for twenty years; and by giving them, in his own farming, a great example of the immense agricultural improvements which may be made, even in the sands of Norfolk, by industry, skill and capital.

Scotch farming has come into existence long since Roger Williams paddled his canoe round Fox Point. In those days the Thistle was the national emblem of Scotland. They fought under it in war, and foraged upon it in peace. But the unpoetical farmers of Caledonia have lost all delight in pursuing the thistle's beard, with the heroes of Ossian; or sleeping on the blooming hether with the bucaniers of Roderick Dhu. They have ploughed down all those things, which look so pretty, and smell so 
sweet in song; and given up those haunts of the muses, to plain English barley and wheat;-Dutch and Swedish turnips; the clover of Flanders, and the Shamrock of Ireland. In the progress of these improvements, these men have done, what Scotchmen think an essential service to that country; but what American farmers, would think a curse to this-they have, by increasing a demand for labour, nearly doubled the price of it; but these industrious, intelligent Scotchmen, with their national prudence, have contrived not only to pay this augmented price of labour, but to replace all their capital; and add to it, at least fourteen per cent. per annum. A farmer in the Lothains of Scotland, who cultivates 700 acres of land at a rent of $11.10 s$. sterling per acre, will, at the end of the year, have in his pocket, clear of all expenses, more than $\$ 3500$. He has so much to add to his capital, and to enable him to extend his cultivation.

By such means the agricultural capital of that country has, from year to year, and from generation to generation, been augmenting. What it is now exactly, I am not prepared to state; but, twenty-five years ago, it was, by men best acquainted with it, calculated at 450 millions of pounds sterling in the whole united kingdoms. This comprehends as well the circulating capital of yearly husbandry as that which is invested in permanent agricultural improvements. While English farmers have been raising and working this capital, we have not been very solicitous to copy their example. The great plenty of lands has induced us rather to reclaim new fields than to fertilize old ones. Our worn out fields, like our worn out horses, have been thrown out to die in the commons. Had we been as provident, as our merchants and mechanicks, we should have imported from England, every agricultural improvement, as they have every commercial and manufacturing one. 
Perhaps, in no nation of the world, has commerce been advanced with such rapidity, as in our own country, since the revolution. When the first India ship sailed from Providence the sight was thronged with as much concourse and viewed with as much anxious admiration, as followed the fleet of Columbus unmooring from the shores of Spain. Now such things are a matter of daily occurrence; and no more is thought of sailing to Canton by the Pacifick than used to be said of sailing round Cape Cod. Then peril and success were a matter of conjecture. Now enterprise, experience and science have reduced them to fair and probable counting-house calculation. Our merchants will tell you the productions, and the exchangeable value of them, in every country and island washed by the waves of the ocean. Nay they will give you the price current of every event, which may jeopardize property, wherever a sail may be spread, or an oar sweep the water.

They have called the aid of the most powerful agents of nature to overcome the opposition of winds and currents. It is within the memory of all of us, how much the western States suffered to transport their produce by water to a market. They might sail with ease, and velocity down the broad Mississippi. It was the voyage of Avernus, "smooth the descent and easy is the way." But Orleans was literally the "bourne from which no ocean-traveller returned." Now, the application of steam to navigation, seems to have put the waters of those mighty rivers into the control of the merchants of the west; and they roll their current back to theirsources, freighted with the productions of the world, with as much ease as a boy could tip a reed in his hand so as to pour the water out at one end or the other, at pleasure. There is nothing like this in any other part of the earth. It is an era in the commerce and mechanism of the world. the age of the American Fulton. 
Mechanicks and manufactures have in their progress far out-stript commerce. Forty years ago there was not a spindle, worked by water, on this side the Atlantick. Since then how immense the capital by which spinning and weaving machinery are moved !- How many-how great-how various the improvements. The cotton is taken from the fields, thrown into these engines of industry, and received back again a fabrick fit for consumption. As you travel along the banks of our streams, the morning sound of our waterfalls is mingled with the merry notes of the bell, calling, not the lazy, lounging monastick to yawn over his matins, but the vigorous, active manufacturer, to the conduct of the spindle and the loom.

The farmers of Flanders erected a statue in honour of him who introduced into their country the culture of potatoes. What shall the people of Rhode-Island do for him who first brought us the knowledge of manufacturing cloth by machinery moved by water? In England, he would, in life, be ornamented by a peerage; -in death, lamented by a monument in Westminster Abbey. Let not the rich, in his adopted country, envy the products of his labours, and his talents :- -his extensive opulence ; - his fair and elevated character. Let the poor rise up, and call him blessed ; for he has introduced a species of industry into our country, which furnishes them with labour, food, clothing and habitation; and that too, when the long and hungry winters of our climate lock up all other employment from them.

It may be said, I think, without any fair imputation of national vanity, that the United States, and the State of Rhode-Island in particular, has, during the last forty years, made a more respectable progress in commerce, mechanicks and manufactures. than any other nation or people. 
I would to God we could say the same thing of agriculture. Our merchants carry the goods of all nations, who will admit them to their trade; our manufacturers export their finished work to the amount of millions. What do our farmers export? Alas! we do not raise enough for home consumption. The bread we shall this day eat was grown, perhaps, in Virginia. A very great part of the supply of our meat, bread, butter, and cheese market, is derived from our neighbours. Many tons of vessels, and much capital, are employed in the importation corn and flour trade for home consumption; and many gentlemen have made handsome estates in this business. Might not all this have been realized by agricultural men, if they would but raise these articles on their own lands? Do not say corn and flour cannot be grown in our State, to any considerable extent. Our State is peculiarly fitted for the growth of Indian-corn, "that prince of crops," as it is denominated, by Col. John Taylor, of Caroline county. Any field which will produce fifty bushels of corn, might also produce thirty bushels of wheat. Wheat grows luxuriantly in Maine, Vermont, Canada, Nova-Scotia and Scotland. Can our climate be too far to the north then? It cannot be too southern neither, for, if you run down the latitude to the equator, you will find it in every parallel, flourishing and abundant, in proportion to the fertility of the soil.

As I said before, no country is better circumstanced for agriculture than Rhode-Island. The government is perfectly free; and it is in the hands of the great body of the freeholders of lands in the State. It is a government of agricultural men, both in this State, and in all the other States, and in the United States. Whatever benefit agriculture can derive from law, may in this State be realized. Frederick the Great of Prussia used, annually, to expend $300,000 \%$. in the encouragement of agricul- 
ture. He was wont to say to his parsimonious courtiers, who might think this liberality better bestowed on them, that he was but spreading his manure for a next year's harvest ; and he did indeed reap it. For, without oppressing his people, and after sustaining numerous, heavy, and sometimes, very disastrous wars, he left to his successour a treasure of 53,280,000 dollars. If it may be questioned, whether government should encourage one kind of industry more than another, yet it cannot be doubted, that a wise government, should encourage all. Arts of utility should grow up together; and so they do, when unaided. But then it is with frequent obstruction, and sometimes, some of them, are nearly extirpated, by adverse events. But let them be nurtured by the fostering hand of government, and they flourish indeed; and soon become the strength, the defence, and the ornament of the State.

On this subject of encouraging agriculture by government I cannot do better than speak the words of the celebrated Watson, bishop of Landaff: he says, "the agricultural improvements, which have hitherto taken place (in England) amongst us, have been by the expenditure of private wealth; but the country cannot be brought to that perfection of cultivation of which it is capable, unless individual efforts are aided and accellerated by publick wisdom and munificence. I boast (says he) not of any particular patriotism, but I would willingly pay my share of 20 or 30 millions of pounds sterling of publick money to be appropriated by the legislature to the agricultural improvement of Great-Britain and Ireland. This appears to me an object of far nearer concern to our independence as a nation, than any extension of commerce or an acquisition of distant territory ever can be. If the time had fully come when an unproductive acre of land could not be found in either of these our fortunate islands we 
should then have food within ourselves for the annual sustenance of at least thirty millions of people; and with a population of thirty millions, what power in Europe or what combination of powers will dare attempt our subjugation."

It is not for me to suggest, in what way the legislature of our State should encourage Agriculture; but I would observe that, in many other States, societies for the encouragement of domestick industry are under the immediate patronage of the government; and funds are appropriated to their benefit in every county, so soon as they by their own means shall raise a fund of a certain amount.

What are most wanted in our country are agricultural books-improved instruments of husband$r y-a$ general emulation to acquire knowledge of the best modes of farming-and a greater, a much greater, appropriation of capital to the business. Do not suffer your prejudices to be awakened when I mention books. Every other art and science is now to be found in the books, which have been written by the great masters of those arts and sciences. If you wish to acquire knowledge in merchandise, mechanicks, manufactures, law, medicine, theology, mathematicks, geography, or any other of the great sciences of utility or ornament, you get books. Why should agricultural men disdain to be taught by the wisdom of the sages and practitioners of the art, who have lived before them? Their knowledge has been committed to books; and these may, as easily be obtained in other countries, as we can here obtain the NewYork primer, or Mr. Aldens' Columbian exercises. I agree they are scarce here and that is the great cause why we are so little acquainted with the agriculture of other countries or with the principles of the art in our own.- When I have inquired for agricultural books, I have been told that there was no call for them and that therefore booksellers did not put them on their shelves. 
More, and different, and better agricultural instruments are much needed. Our ploughs are far from the best; our harrows quite indifferent; rollers, cleaning rakes, scarifiers, drills and thrashing machines are, I believe, not used at all in the State. Let me tell you, that I know the ploughs in use among us, are not so good in any one point of view as Wood's New-York cast-iron plough. This plough may be moved with a power, one quarter less, and will then do one quarter more work, than any other plough in use in the State.-I know of four of these ploughs, which have ploughed at least 120 acres this season; and the whole expense of keeping them sharp and fit for use has not exceeded 56 cents each. 'The blacksmith's bill for ordinary wooden and wrought-iron ploughs, for the same work, would have been at least $\$ 5$ more for each plough. It will be found that not less than $4 s$. per acre will be saved by the use of these ploughs; and the work done in every respect better, than it is done by any other. In the State are somewhat more than 85,000 acres of land exclusive of the waters. We may reckon 72,000 , as the number of acres contained in the farms of the State; and 1-6th part of this, or 12,000 as under the plough; so that to save $4 s$. per acre, on this, will save $\$ 8000$ to the farms of the State. Do not say that these ploughs will break easy. I knew one of them last year to break a piece of tough sword land of ten acres, well packed with paving-stones through its whole texture and which had probably not been ploughed for 30 years. It was drawn by six oxen and did the work well. 'The same plough and team broke a piece of new ground thick with green white-oak stumps. It stood both of these severe operations. Another of these ploughs I have seen repeatedly bring to a dead stand against a rock, a pair of strong horses moving at a quick step and ploughing a clover lea in the dryest time of last year's summer. 
Scarifiers are instruments calculated to do the work of a plough and a harrow. They are in common use in England. I know of but one in this part of the country. In Scotland they make them entirely of cast-iron. In all lands free of stone or where the stones are loose and not too large to pass between the shares and teeth and on which a crop has been raised, a man and a pair of horses or a pair of such oxen as work the Smithfield lime wagons, will prepare the ground and get in the grain on 30 acres in a week. In England a man with 4 horses and the broad scarifier has been known to do 60 acres of wheat in a week.

In the common method of doing this work two men or one man and a boy, with a pair of oxen and a horse are employed and they hardly finish an acre per day. It is then to be harrowed or bushed or both. What will it all amount to? I have known this year 15s. given for getting in oats on Indian hills. Perhaps it was rather too high. If done with the scarifier it will not cost $2 s$. per acre. The use of the scarifier would save to the agriculturalists of the State $\$ 10,000$ per annum.

The heavy roller is an instrument of great utility. It reduces clods-pulverizes the top of the ground-levels and smooths incomparably better than any other instrument. When a field is cleared of the larger stones and mellowed sufficiently deep for a crop of grain, this instrument sinks every other stone below the course of the scythe, and saves the expensive task of gathering them from the grass which every farming man who has been a boy may know, is so toilsome and tedious.

Could I persuade the farmers of this State to introduce the culture of root crops for feeding stock, I should recommend to them the use of the drill. It will perform the labour of ien men.

Thrashing mills are very common among English and Scotch farmers, and are far more ex- 
peditious than the flail or even that filthy praetice of treading out grain with cattle. A four horse mill will thrash and clean 600 bushels in ten hours. It is a fact known to farmers who use this machine that 1-20th more grain is obtained from the same quantity of straw by it, than by any other method of thrashing.

Mr. Brown of Markle, in his treatise on rural affairs, presents the following estimate of profit which might be derived to the English publick by the universal adoption of thrashing-mills : he calculates,

1. The No, acres producing grain in Great-Britain, $8,000,000$

2. Average production in qu. at 3 qrs. per acre, $24,000,000$

3. The increased quantity of grain 1-20, $1,200,000$

4. The value of that increased quan. at 40 s. per qu. $2,400,000$

5. Saving in expenses of labour at 1s. per qu. $\quad 1,200,000$

6. Total profit per annum, $\quad 3,600,000$

It is not wonderful then, says Sir John Sinclair, that he should pronounce the thrashing-mill the most important machine in the farmer's possession and the greatest improvement that has been introduced into Great-Britain during the present age.

The introduction of all these implements into the farming of this State would save the agricultural interests not less than $\$ 50,000$ annually. This would add considerably to the capital already appropriated to that department of industry.

On the subject of agricultural capital I fear the most of our farmers will not willingly agree with the experience of the best farmers in this and other countries. I need not tell such men as I am addressing, that every branch of industry will flourish in proportion as it shall be well or ill supported by capital. If factories and ships cannot be moved without this great impetus, neither can the plough. be put in motion without it. It is the great vital principle giving life and motion to human labour and accelerating and multiplying all its various productions. 
Some travellers who have passed through the finest districts of France are charmed with its agriculture; but those who have inspected the whole kingdom, know its immense inferiority to England. France is a land of vineyards and olives; England of wool, wheat and beef. But nothing, it is believed, will so strongly illustrate the difference in the agriculture of the two kingdoms, as the difference in the capilal employed in each. In the United Kingdom of Great-Britain are 98,000,000 of acres, $15,000,000$ of people, and $275,000,000$ of pound sterling employed in farming capital. In France are 130,000,000 of acres, $26,000,000$ of people, and $262,000,000$ of pounds sterling in agricultural capital. With nearly a third less land and but little more than half the population, England has $13,000,000$ of pounds sterling the superiority in capital. This has reference to the circulating capital of yearly husbandry. In permanent improvements belonging to tenants and not to landholders, England has almost as many millions more, and France almost nothing. These calculations have reference to the year 1798 .

Since that period the improvement in English agriculture has nearly doubled the capital of that kingdom, and nearly a double amount of capital is necessary to cultivate an English farm now, to that which was used in 1798 . From the writings of Sir John Sinclair published in 1817, it appears that to cultivate a farm of 700 acres in grass and grain, according to the improved system of English agriculture, will require a capital of at least $\$ 25,000$. With this capital on an improved farm, at a lease of 20 years, a skilful, enterprising, industrious man clears 14 per cent. per annum on the whole amount of it.

To cultivate the state of Rhode-Island in such a manner would require nearly three millions of dollars in farming capital, exclusive of the value of the 
dands. I fear the sum employed in that branch of domestick industry at this time, in the State, is considerably short of that amount. But suffer me to say, that until agriculture is encouraged by a greater appropriation of capital, it cannot reasonably be expected to grow and flourish among us.

You will forgive me, gentlemen, when I say, that I fear our system of agriculture is far from being the best now in practice among farmers of science and skill. It surely does not become me to tell my farming fellow-citizens that they are ignorant of their trade. But if an English or Scotch farmer should remove into this State, with a capital of $\$ 60,000$, intending with 30 of it to purchase a farm, and with the other 30 to cultivate that farm, do you believe he would manage his farm as we do ours? If so, he might loan or set up a money shop with 29000 of it, and still have enough for common New-England farming. Yes, such a capital would (so he would be told by many sharp men) make two good substantial banks, if he would only let them call in about fifty of their clever uncles, cousins, brothers, fathers and sons to be directors, presidents, cashiers, clerks, rumers, setters and brokers, all of whom they would assure him wished to join in banking, because every one of them were now much in the way of doing business at banks. I think the Scotch or English farmer would say to them, that he did not understand banking so well as they seemed to understand it, but he had some knowledge of farming, and besides he wanted all his capital, and wished to hire a few thousand dollars more to complete the stocking and improvement of his farm. In managing of it, I think he would particularly attend to enclosing, clearing, and draining, a course of crops, and a system of manuring.

The enclosing his farm would be governed by the materials on the land, the nature of the soil. 
and the course of crops to be pursued. I will not believe such a man would buy a farm without being satisfied that he could render every acre of it practicable to the plough. If his lands abounded in stone, his fences would be made of that material; if not, be assured that ditches, and thorn hedges would form the outlines of all his fields. This kind of fence is less expensive than posts and rails, and as durable as trees continually growing can render it. The beauty, strength and efficiency of these fences cannot be exceeded. The finest walls will sometimes be leaped by sheep or cattle, but these hedges are impassable by any animal unaided by wings.

In dividing a farm into separate enclosures the clays should be separated from the sands, for these require different crops and different treatment. Some tracts of land are most productive in perpetual meadow, and some in the convertible course of tillage, and perhaps all light lands, unless where consolidating manures may be easily obtained, should be pastured one or more years in the course of every rotation. Although large farms should have large fields, yet small ones need not have proportionally small fields, for the same field may be appropriated to different crops in the course, and the expense of division fences saved.

Clearing is ths next subject of attention after enclosing, and where the land abounds in stone, it is performed at the same time; for by clearing, an English farmer means not only extirpating trees and bushes, but also removing rocks and stones, or whatever will obstruct the course of the plough. This at first view seems like a labour of Hercules, and hardly practicable in some places. But when land is covered with a forest of 100 cords of wood to an acre, is it not an immense labour to reduce it to cultivation? This, however, is readily done, because it is impossible to crop the land without 
doing it. Let us but believe that we cannot cultivate our fields until we clear them of all fast stones, and all those too large to pass freely between the teeth of a horse harrow, and we shall set ourselves about removing these obstructions with the same unconquerable perseverance with which a New-England man first lays his axe to the root of the oak in the forest of Ohio. If the expense of removing rocks and stones should be $\$ 50$ per acre, these obstructions, when removed, are worth the money for erecting fence, and the whole cost will be saved in the course of the first seven years' rotation of crops.

Draining is a subject of great importance to the Rhode-Island farmer, for in our burning climate those are the best lands which are reclaimed from the water. Moist clays, bogs and morasses, are better for the plough than for timber; but these must first be drained. Draining must be conducted on geological principles, or the labour is lost. The common method is to run a ditch through the lowest part of the land intended to be drained, and because this is never found effectual, it is concluded that the land cannot be laid dry by ditching.

Men of science will assure you, both on principle and from practice, that in all places where there is a sufficient fall, any piece of land may be as effectually drained as a pond may be. Such men tell us, and experience tells us the same, that the earth is disposed in layers or strata. It may be of loam, of clay, of sand, of gravel, coal, slate, oar. These strata spread themselves over the level parts of the earth, and up acclivities with much uniformity. But as you approach the tops of hills and mountains, the upper strata and especially the very upper, are broken and separated; and upon opening the earth will be found to stand somewhat on edge, or at an angle, more or less inclining to the zenith as the hill is more or less elcvated. Thus if you take a two feet globe, and cut 
a piece of morocco leather just large enough to cap it from the pole to the equator, and having tacked this piece upon the globe, cut five other pieces of exactly the same size, you will find the two or three last pieces will not reach down to the equator; but draw your knife across them two or three different ways, so as to cut them through at the pole, and you may tack them down at the equator, in a line with the first piece; then turning the globe so that the pole will be exactly on the top, pour water upon it and you will find it passing into the cuts made with your knife, and running out between the different layers of leather at the equator.

This, perhaps, is a pretty correct representation of high and low land as it respects water falling from the atmosphere. The water ascending in vapour, is condensed about the cold region of hill and mountain tops; and falling upon them, passes through the broken strata of their tops, and running down between the different layers, sometimes breaks out upon the mountain or hill's side, in springs, but most commonly, issuing from their bases, forms rills, brooks and rivers, or meeting with some obstructions, spreads itself out into ponds or lakes. These in the progress of years by the wash of the mountains, the falling of leaves, plants and trees, into them arefilled, and the decomposing powers of the waters, changes all these alluvial materials into mosses, bogs and morasses. If you would drain these, you must remove the cause which has supplied this quantity of water. In the experiment just now mentioned of the globe, half covered with layers of leather, when you have set it up before you and have poured the water upon it at the pole you will see it gushing out at the equator in a number of places. How will you prevent the falling of this water upon your table? Take one more strip of your morocco leather, perhaps half an inch wide, fold it together edgewise, like the old fashioned 
rand of a shoe, tack the inner edge of it exactly to the edge of your first and innermost layer of leather on your globe; and forming a conductor, it will catch every drop of water which you may pour on to your globe. Make a notch with your knife on the outer edge of this conductor, and you may run all the water into your glass again.

Do not call this trifling - it illustrates the whole great system of draining-a system which if thoroughly understood, and universally practised would add one third to the fee simple value of the lands in the State. If you draw a ditch round the bottom of a hill or just where the upland and swamp blend themselves, in such a manner as to surround the whole marsh and settle it to a sufficient depth, you will cut off every water course which has formed the morass. Let this ditch be conducted to the lowest point of the ground, and if there be fall enough, the whole body, surrounded by the ditch, will be left in a condition to become, and to continue dry enough for the plough. Throw a row of round stones on one side of the bottom of the ditch, and a row of flat ones on the other, so as to reach and rest upon these-throw in small stone and raise them to a small distance below the deepest course of the plough-spread the whole with a slight covering of straw, and return the earth into the ditch again-you will then have a subterraneous water course, permanent as your fields, and never to be interrupted but by the percussions of such an earthquake as shall not only "topple down towers and temples," but shake the very rocks from the bosom of the earth.

The Scotch or English farmer after he had enclosed, cleared and drained his farm, would consider the climate, soil and market, and then determine his several crops and their various rotations. His broken lands would be appropriated to pasture. His marshes to perpetual meadows, clays 
and heavy loams to oats, potatoes, wheat and all the various grasses for four years-three to be mown and one pastured. The light loams, and sandy lands would, I think, be appropriated to a seven years' rotation. The first two years would be given to clover. Immediately after the second year's mowing, early in July, the clover lay should be manured, neatly ploughed and planted with seven thousand plants of green savoy cabbage per acre -the rows 4 feet distant-the plants one and an half feet. By repeated ploughings and harrowings, and one hoeing, the crop will be abundant and afford a most excellent forage for sheep, cattle or swine, till the month of February. Wheat should be sown and harrowed in about the middle of September. Do not think a Scotchman would be disheartened by the labour of raising cabbage. He would know that a boy 15 years old would plant an acre in a day, and that the whole expense after the ground is prepared, would not exceed $\$ 5$ per acre. The crop will vary from 10 to 30 tons per acre according to the soil and season. The wheat will be harvested by the tenth of July of the next year. The ground immediately scarifiedraked with the rake attached to this instrumentand the stubble burned on the land, or carted to the barn-yard for litter. Furrow the ground 4 feet apart, with a double furrow, drop 30 loads of manure per acre in these furrows-spread it even from end to end of them-turn the earth back upon the manure and roll the ridges. On these ridges if not after July 15th, drill in ruta baga; if much later, set out plants. One or two ploughings and harrowings, and one hoeing, will be the whole culture. This crop must be drawn from the fields in our climate, and cellared or buried in the ground. It is a feed for any kind of stock equal to carrots or potatoes, and will keep sound till the next July. 
The next year the field is manured and appropriated to Indian corn and potatoes. The corn is planted north and south in rows six feet apart and in hills two feet from each other. The rows of potatoes are planted between the rows of corn and at exactly the same distance every way. Ploughs and harrows may move freely both ways among the crops, and one, or at the most, two hoeings will be sufficient.

I am satisfied this is by far the best method of cultivating corn and potatoes. Their different heights give them enough of sunshine and their abundant branches secure to the earth a sufficiency of shade: and I have sometimes thought that a well prepared field will produce two entire crops quite as abundant as either crop would have been if it had occupied the ground alone. The potatoes may be harvested in September, and the ground between the rows of corn harrowed in to rye.

When this crop is cradled from the ground the next year, let it be furrowed three feet apart-manured in the furrows with 20 loads of compost per acre, the earth turned back upon it, the ridges rolled, and two rows of turnips drilled upon each ridge. These turnips should be thinned to 10 inches apart in the rows, but neither be ploughed or hoed.

The next year this field should be manured with 25 loads per acre of compost-the ground well ploughed to the depth of 10 inches, and scarified until perfectly mellow, rolled and made smooth, and then driiled with carrot seed, at two feet distant, row from row and the work finished by the first week in June. This crop should be repeatedly ploughed and harrowed, hand-hoed twice and thinned to three inches, plant from plant.The expense after the ground is prepared, will not exceed 7 per acre, and the crop, if well conducted, exceed 500 bushels. I have seen 600 on three 
fourths of an acre, and I do not doubt that this year I have seen two acres out of six which will produce fifteen hundred bushels. No crop better than this rewards the labour of the husbandman. It is in all respects superiour to potatoes, which have long been considered the principal root-crop of NewEngland. It is more abundant in product, requires less labour, is more easily preserved, for considerable frosts do not injure it, and it affords, in its natural state, a more abundant and better nutriment for all domestick animals.

The next year the ground must be given to clover seed, with oats or barley, sown in the spring, or, after either of these crops have been taken from the land in mid July, plough in the stubble, sow your clover seed and oats with it, to be mown in October for forage. Either of these methods will do; but if the land be rich, as it must be in this rotation, the last is much the most profitable; and the young clover is much less liable to be ruined by the frost of winter, than by the burning suns of summer.

This rotation I think a Scotch or English farmer would follow, so soon as he should understand our soil and climate. It is nearly one hundred per cent. superiour to any thing which is or can be done in England or Scotland. It will give thirteen crops in seven years.

This system too embraces the great principle of all rotations, "never let two white crops succeed each other on the same land." But it cannot be conducted without a large quantity of manure.

To this great object the farmers whom I have been mentioning would give a most devout attention. On this part of the subject, it is possible the nasal criticism of fastidiousness may be offended. But if delicacy shudder at the name of manure, let her learn, that the very gales of Arabia, which " far 
off make old ocean smile," would become arid and scentless as the simoon, were it not for this all invigorating principle. All matter is probably uniform in its original state, and the most fascinating and most loathsome masses of it, when reduced to their primitive condition, exhibit the same elements. The diamond blazing on the diadem of royalty, may have ripened into brilliancy from the cindered and charred carcasses of trees and animals ; and the rose blushing on the bosom of beauty, has doubtless stolen its fragrance from the elaborated effluvia of reeking offal. Do not let us mortals, inch high only as we are, and sprung from the dust but yesterday, greatly marvel at the quality of food which our parent earth is hourly swallowing. She does indeed like a fond mother feed and nourish all her children, in all their various families of plants, trees and animals, and then like a cruel cannibal she feeds and fattens upon them. Not only the humble flower and the lofty oak, but the eye that sparkles and the cheek that blooms, may go the course through which Hamlet traces his king, and

"Great Alexander dead and turned to clay,

"May stop a hole to keep the wind away."

All organized, material substances must submit to the great law of perpetual mutation,

"Like bubbles on the sea of matter borne,"

"They rise, they break, and to the sea return."

The fop and the dandy may start and put his handkerchief to his prominent feature, when masses of the fertilizing principle pass "between the wind and his nobility," but the philosophick agriculturalist will look on them as the great collections of rich ore, to be elaborated by the earth into abundant harvests of golden grain.

On this part of the subject, I had intended to detail whatever reading, instruction or experience 
have thrown in my way, concerning the great principle of fertilization, the various sources from which it may be derived, and the application of it to different soils and productions. It may not now for want of time be done; but I cannot in justice pass it, without some general observations.

By the principles of nature all things capable of dissolution are reduced to it, by air, heat and moisture exciting a fermentation in them. Whatsoever is perishable on the whole face of the earth, is, by certain chemical qualities in the soil, transmuted into the means of producing food for plants. Things most loathsome to the senses pass through this great laboratory, into all that regales and delights them. An universal principle of dissolution and animation pervades the world, and nothing that perishes can be finally lost from the great mass of material nature. Whatever of animal or vegetable substance may be thrown on the streams of rivers, or immersed in the main ocean, is, after being washed into other forms, deposited on their banks or shores, or aiding the growth of marine vegetables, is by the waves driven to land, and may be carried up again to renovate the soil. Every vegetable and every animal perspires many times its weight, in the course of its existence. Around all material substances in a state of dissolution, there is a thick atmosphere of the most volatile particles of them. These are all carried off in the air, and mingling with the moist part of it, alight in dews or descend in showers, to enrich the earth. The air, the earth and water thus unite in one continued effort to give verdure, and bloom, and fertility, and if possible, perpetual youth to the world. Were it not for the success of this effort, the goodly creation had long ago become a "sterile promontory." Take most of the habitable parts of it, and many of them have for thousands of years been scourged with a most exhausting succession of crops; yet not - 
withstanding all this, and all the negligence of their cultivators in collecting manure to fertilize them, they still continue to reward the husbandman with a rich harvest. Sicily was the granary of Rome, then more populous than Paris now, and at a time too when that island had more inhabitants, in all probability, than are now contained in New-England. It has been ever since, and is at this day, quite as productive as formerly. The quantity of wheat produced on a single acre of this island, since its first cultivation, must be almost incalculable. What could have supplied this immense quantity of regetable food? Surely not the manures spread on the ground by the labourers; nor are the Sicilians more skilful husbandmen than can be found in other nations. No soil can of itself be perpetually fertile. Whence then this continued productiveness? Nature is constantly making an effort to overcome the ravages of man, and to restore herself to her original condition. In some places it is more, in some less, vigorous.Parts of the earth are found where it can give perpetual fertility ; in other regions several years are required to restore exhausted lands, and all that ever were fertile would, if left to themselves, in time become so again, by the aid of these mighty agents of nature.

The earth was once a garden; not a dead unvaried level like the shores of the Nile. Lybia had then its wastes of sand. Europe was covered with green fields, American mountains heaved their snowy heads to the clouds. The brown regions of Asia were spread out into immeasurable plains ; rivers then as now swept along in silent streams, or thundered down in cataracts, and ocean rolled his mighty confluence of waters, and with his billows laved all the shores of the globe. This was indeed a garden, rich in all the varieties which could be spread upon it by that hand which gar- 
nished the heavens. Man, awaking from the dust, gazed on all things round him, and if not satisfied with what his eye could reach, might in fancy lift himself from the hill-top he had climbed, and look down on the globe rolling beneath his feet, and presenting to his eye all the rich regions of the earth. How naturally did he exclaim,

" Needs must the Powrer

"That made us, and for us this ample world,

"Be infinitely good."

This world might still be a garden ; the curse of human disobedience was not spread out upon the soil-no; man, who was by heaven placed in this garden to dress and tend it, became by disobedience what he is now, unmindful of this great command, and scourged some parts of it down to barrenness, and suffered others to grow up into weeds and briars and brambles. The Power that rules us produces all effects by general laws. It is the duty of man to bring particular cases with the influence of them. This requires labour, but Paradise itself was not exempt from it. We have a country grateful to the hand of cultivation, genial suns, refreshing dews, enriching showers, various soils, and abundant materials to restore fertility to them when exhausted. Let every hill and vale and plain teem with the most abundant harvest; no surplusage will be left to perish on our hands. Only drive violence and robbery from the great highway of nations, our commerce unrestrained will unite these shores with other continents, feed and clothe the people of a thousand realms with the harvest of American fields and the fabricks of American looms, and in exchange pour into the lap of our country the wealth of every quarter of the globe. 


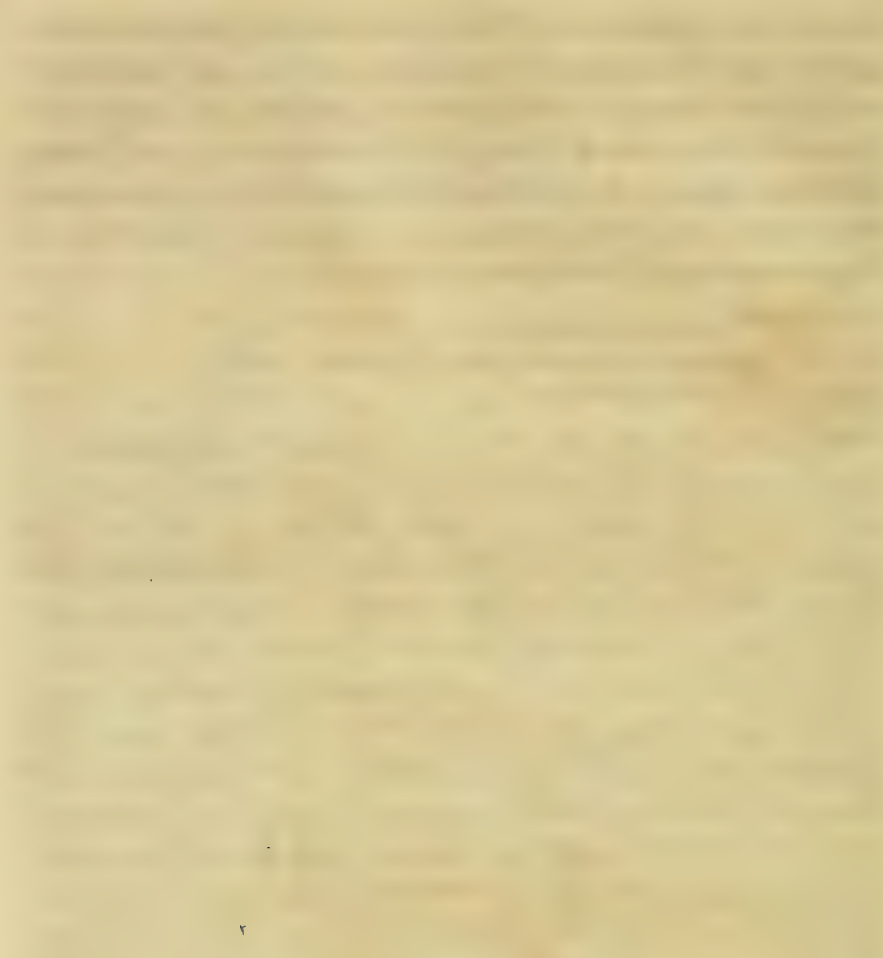




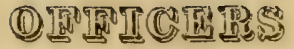

Of the Rhode-Island Society for the Encouragement of Domestick Industry, for the

present year.

JAMES RHODES, President.

SAMUEL SLATER, 1st,

JAMES D. WOLF, 2d, Vice-Picsidents. SAMUEL KING, 3d,

- Stañford Newel, Treasurer.

William E. Richmond, Sccretar\%.

Standing Committee.

PHILIP ALLEN, JESSE TOURTELLOTT, DUTEE ARNOLD, RICHARD ANTHONY, DEXTER 'THURBER, SAMUEL GREENE, CHRISTOPHER RHODES, ALBERT C. GREENE, THOMAS BUFFUM, JEREMIAH THURSTON, WILLIAM WILKINSON, NATHAN BOWEN, CHARLES DYER, FREEBORN SISSON.

\begin{tabular}{|c|}
\hline $\begin{array}{l}\text { ELISHA OLNEY, } \\
\text { JESSE BROWN, } \\
\text { JOHN JENCKES, } \\
\text { GEORGE D'WOLF, } \\
\text { STEPHEN T. NORTHAM } \\
\text { JOHN HOWLAND, } \\
\text { JOSEPH S. COOKE, } \\
\text { JOHN B. FPANCIS, } \\
\text { GIDEON SPENCER, } \\
\text { WILLIAM HARRIS, } \\
\text { GEORGE W. TILLING- } \\
\text { HAST, and } \\
\text { ASHER ROBBINS. }\end{array}$ \\
\hline
\end{tabular}




\section{2}






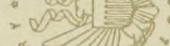

40

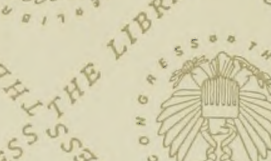

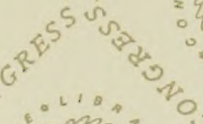

inis.

\&

30

siv

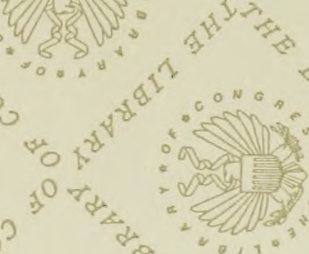



समें

का

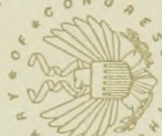
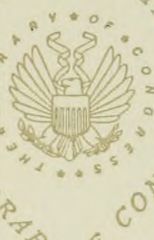

40

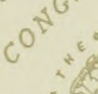

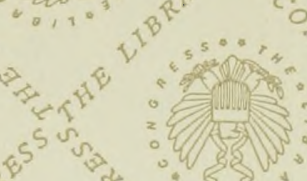

(2)

$:=$
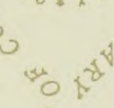

${ }_{1}^{0}+\frac{1}{2}$

(1)

"

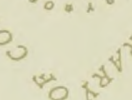

${ }_{3} \mathrm{O}-2$

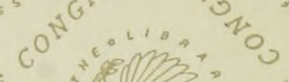

"s

$40 x^{y^{2}}$

से०

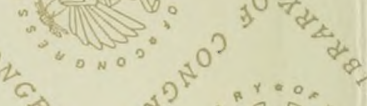




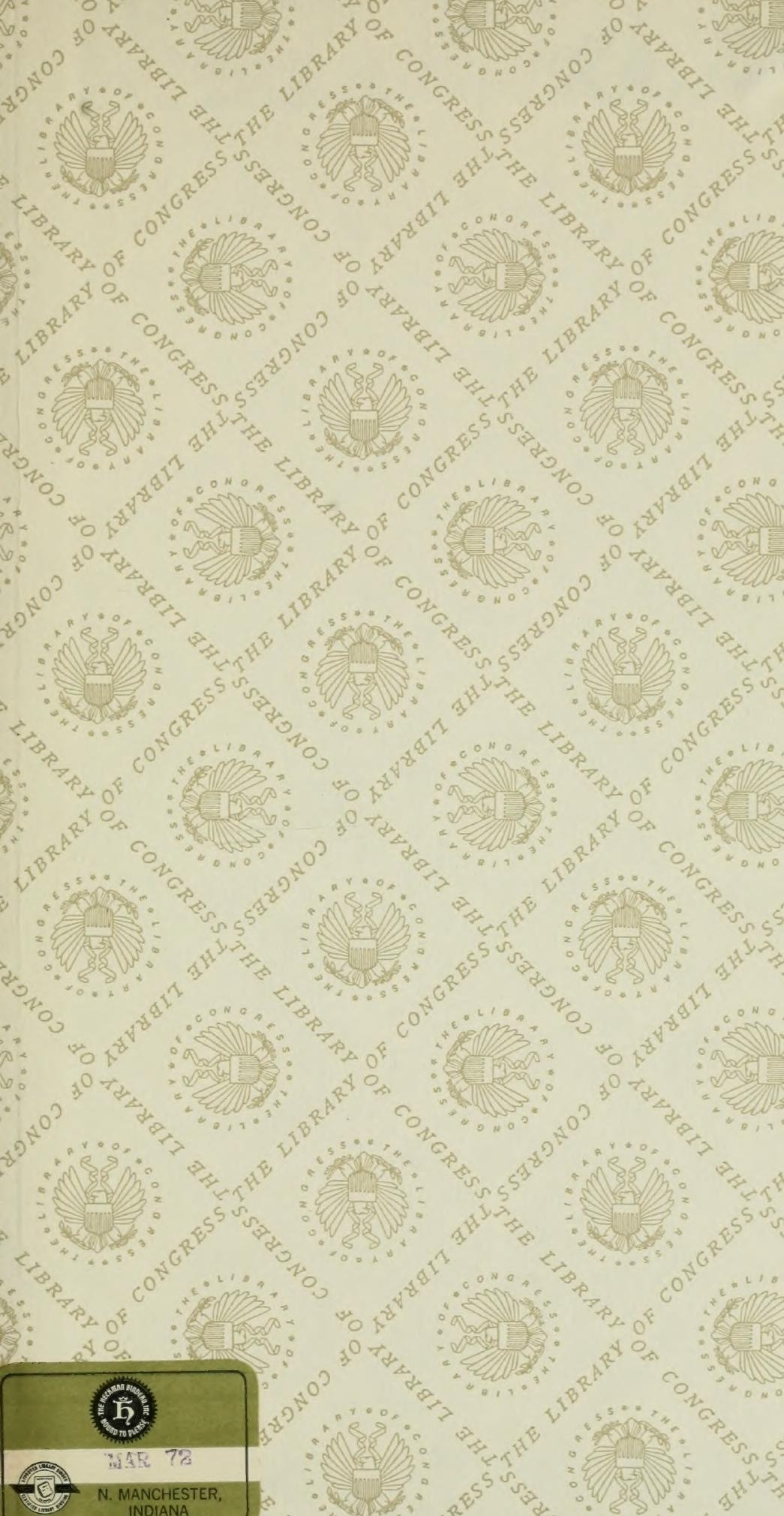


LIBRARY OF CONGRESS

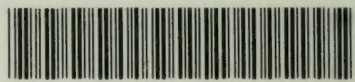

000274 41208 